\title{
Globalisation and its impact on the creation of sustainable points of purchase
}

\author{
Daniela Kollarova ${ }^{1, *}$ \\ ${ }^{1}$ UCM, Department of Marketing Communication, 91701 Trnava, Slovakia
}

\begin{abstract}
In the second half of the 1990s, important global traders began to come to the Slovak market, changing the functional layout of the towns and cities by building large-scale stores, bringing new formats and forms of selling to retails, as well as thoughtful external and internal shop designs. More than twenty years have passed since then, however, internationalmarketers continue to shape the Slovak retail market, this time through a sustainable architecture of shops and logistics centres, responsible product assortments, reduced food waste, separating and reducing paper or plastic packaging and batteries, changing the employees' clothing for garments from organic cottons, and so on. They have namely realized that the environment is more affected than protected as a result of globalization, and it is therefore necessary to take measures to protect the natural world with regard to permanently sustainable principles. The object of our research is the shopping setting in retail stores of selected worldwide retail chains operating in Slovakia, i.e. all elements of the retail shop and its operation (its design, layout, goods presentation, staff and customers), in the context of sustainability. We are looking for answers to the questions of which selected global retail chain stores working in Slovakia and by implementing of which specific measures they build sustainable points of sale. In the process of elaborating the paper we used as sources of information relevant publications, proceedings of scholarly papers, as well as studies available at the Internet sites of specialized journals. At elaborating the sources, we applied standard scientific methods: researching, description, analysis, and deduction.
\end{abstract}

\section{Introduction}

In the second half of the 1990s, crucial international marketers started to penetrate into the Slovak market, while with the construction of large-scale stores they changed the functional layout of the towns and cities. They also provided new sales formats and forms, along with well-considered external and internal designs of the shops. Thus, globalization came to the Slovak market [1,2]. Although more than 20 years have passed since then, worldwide traders go on forming the Slovak retail market, this time with a sustainable architecture of their shops and logistics centres, reasonable range of products offered, decreasing food wasting, separating and reducing the amount of paper or plastic packaging and batteries, choosing clothing from organic cotton for their employees [3], and so on. They have

\footnotetext{
* Corresponding author: daniela.kollarova@ucm.sk
} 
namely come to a conclusion that the environment is rather badly affected than protected by globalization, and therefore it is vital to take steps to preserve our natural world while taking into account permanently sustainable principles.

The subject of our examination are components of a retail shop and its operation (the shop' s design and layout, exhibition of the goods, its personnel and customers) [4], by selected international retail chains working in Slovakia, in the context of sustainability. In the broadest sense, the point of purchase may be explained as any place, on which there comes to the execution of the sale, however, for the needs of our exploration we understand it as a retail shop. The terms, such as sustainability and permanently sustainable development, began to be used at the beginning of the 1970s, especially in relation to the knowledge that any uncontrolled growth of either population, production, consumption or pollution, is not acceptable in the setting of limited sources. Permanently sustainable development does not cover only the environmental issues, but also sustainability of the economic growth and social cohesion [5].

Since retail trade is the second largest employer after industry in Slovakia, and in 2017, $22.1 \%$ of companies in Slovakia were operating in retail and wholesale, [6] it is necessary to narrow the number of the examined international retail chains. Therefore, we have decided to include worldwide retailers who were awarded the Mastercard Merchant of the Year 2018 award. Mastercard Merchant of the Year is the prize for the best traders in individual categories of goods in retail, which reflects the retailers who have long enjoyed the loyalty and trust of the customers [7]. As consumers decide about the winner, we can assume that award-winning merchants have the ability to significantly influence their clients, also in terms of environmental and sustainability issues. Since the Slovak households spend an average $€ 249$ per month on food and personal hygiene products [8], we have restricted our selection to global traders awarded in the category Food and Miscellaneous Goods in 2018, which includeLidl, Kaufland and Tesco [9]. At the same time, these merchants belong to the top three in perspective of the reached takings in retail [10].

\section{Globalization and sustainable points of purchase}

The term globalization was first used by Theodore Levitt in 1985 to describe the evolution of the world economy in the decade of the 1980s; in our times it isapplied to characterize the current and expected development in the future. Although the explanation is rather general and inconsistent in different sources, it has following common features: new communication technologies, unlimited capital markets, trade liberalization, and real-time reachability of any place in the world [11]. Some of them are transformed into concrete measures of selected international retail chains operating in Slovakia to build sustainable points of sale. We ranked the steps according to individual components of a retail shop and its operation: point-of-sale architecture and technology, sustainable and environmentally friendly business facilities, recyclableassortments, food waste and sustainable customer communications.

\subsection{Sustainable architecture}

In 2016 the chain Lidl started to build more modern shops equipped with advanced technologies, contributing to permanent sustainability, for example, energy-efficient LED lighting throughout the building, heat recovery from refrigeration and freezing equipment that contain natural refrigerant;free charging stations for electric bicycles and electric vehicles; or instalment of photovoltaic panels on the roofs of the stores [12]. On the site of 
the logistics centre Lidl of the Next Generation in the town Sered', they even placed water retention tanks and carried out landscaping measures on an area of 2.5 hectares [13]. As a part of sustainability, since 2019 Lidl has been supplying its stores in densely populated areas by ecological trucks with combined CNG/LNG propulsion, which produces almost no emissions [14]. The companies Kaufland and Tesco have also changed their lighting not only because of being environmentally friendly, which is part of their corporate social responsibility, but also due to the energy cost savings in their shops, which reach around 30 $\%[15]$.

\subsection{Sustainable shop equipment}

As a part of its sustainability strategy,Kaufland hasgradually shifted from disposable fruit and vegetable cartons to multiple-use cratesin all its European stores. In Germany, customers could come across with them as early as in 2003, in Slovakia they started to be used only in 2015, and since the end of 2018 green carrier boxeshave been the standard packaging for most fruit and vegetables in all Kaufland stores in Europe. In practice, this means that fruit and vegetables are found in only one organic container during the entire logistics process from the distributor to the store location. Kauflandcalculated that by implementing these cratesin 2018 , it managed to reduce $\mathrm{CO}^{2}$ by approximately 35,000 tons per year. [16].

The EU regulation on the permanent reduction in the consumption of lightweight plastic bags does not apply to HDPE bags, yet the retail chain Kaufland, in addition to its statutory obligations in 2019, introduced organic nets in its stores as an alternative to HDPE bags for fruit and vegetables. Thesenet bagsare made of $100 \%$ organic cotton and are GOTS certified, which means that they meet international standards for organic textiles. Currently, they are purchased and used by customers on a voluntary basis. Nets are reusable, one package contains three pieces for the price of $€ 2.99$ [17].

\subsection{Sustainable assortments}

One of the problems of our times is plastic waste. Therefore, global traders have decided to significantly reduce the volume of plastics at their points of sale, also in relation to the range or items offered, as follows:

- Plastic bags. In 2017, Kauflanddiscarded the best-selling lightweight plastic bag and replaced it with a textile bag from organic cotton. Lidl decided to remove the thinnest plastic bags from its sale in 2018.

- Plastic packaging. Retail chains strive to remove plastic packaging or replace it with more environmentally friendly variants for as many products as possible. As a part of its strategy to reduce plastic waste, Lidl approached to reduce the packaging of washing gels, nuts, dried fruits and to reduce the weight of PET bottles of its own brand of soft drinks. Kauflanddiscontinued the use of micro-plastics in the manufacture of its own skin and body cosmetics, as well as detergents as early as in 2013. And Tesco intends to remove hardly recyclable materials from its own brands packaging by 2020 and to achieve $100 \%$ use of recyclable packaging in products of its own brands by 2025 [18].

- Plastic dishes. At present, Lidl only sells out disposable plastic dishes such as cups, plates, cutlery, but also plastic straws. In May 2019, Kaufland also removed from saledisposable plastic dishes and disposable plastic straws. As a result, annually the chain globally relieves the environmentalburden of over 6 million disposable plastic cups, 5 million pieces of disposable plastic cutlery and dishes and nearly 1.8 million 
disposable plastic straws. The plastic dishwarewas replaced by paper one, which is reusable.

- Weight reduction of PET bottles of soft drinks. Lidl was the first to do this with its own brand of drinks. The adjustmentalso applies to the packaging plastic films.

\subsection{Food waste}

Apart from hardy recyclable materials, another major problem highlighted by international retailers is food wastage. Reduction of food waste is of great importance in a global context. ,In terms of the environment, food losses and food wasage account for about $8 \%$ of greenhouse gas emissions. If food losses were a country, they would represent the third largest source of emissions after China and the USA." [19].

As the first and so fat the only retailer in Slovakia, Tesco is aware of its responsibility to combat food waste. In 2017, it started to measure food wastage at its points of sale and transparently publish the data obtained. In two years (2017 to 2019), it managed to reduce food wasting in its stores by $52 \%$.

„In the financial year 2018/19 Tesco Slovakia sold 559, 464 tons of food, while generating 8, 614 tons of food that was not sold to the customers. "[19] This volume includes food suitable for human consumption, animal feed, but also food unsuitable for further consumption and disposed of as waste.

\subsection{Sustainable communication with customers}

Kauflandhas been communicating with its customers in the field of the environment protection for a long time, because it believes that if they are sufficiently informed about greener alternatives, they are more likely to change their purchasing behaviour [20]. A famous person, Eva Kramerová, has been featured in the campaigns,, You can't be chic with a plastic bag" and „From now on only into a net bag“, which are presented on TV, in the online environment, but also at the points of purchase.

In 2018, Lidl decided to optimize its product circulars, saving nearly 2, 400 tons of paper per year. The change was achieved by replacing the A3 format by A4 and reevaluating the distribution network. Since early 2018, it terminated the distribution of circularsin about a third of the regions. It motivates customers to subscribe to electronic newsletters, follow offers on the website, Facebook profile or application. Product leaflets of Lidl are printed on paper with low environmental impact [21].

From the viewpoint of marketing communication of the campaign of the company Tescoin the area of the environment, or sustainability, it informs about its steps, such as decreasing food waste, orelimination ofplastic bags from the sale, in the form of news releases. However, Tesco also supports selected activities of other subjects, for instance in May 2019 a press conference of the Ministry of the Environment, which in one of the Tesco stores in Bratislava pointed out the importance of bees and butterflies for the production of food and sustaining biodiversity by illustrative presentationof empty shelves [22].

\section{CONCLUSIONS}

The commitment to take permanently sustainable steps is a reflection of the promises and objectives of the entire group consisting of Tesco, or Schwarz, while taking into account local specificities.A compromise that respects global marketing strategies as well as specifics or peculiarities of the local market is the basis for the success of international marketers. Each of them is aware that they will not be able to meet their ambitious goals 
without the help of suppliers, companies dealing with waste and packaging management, as well as other retailers. For instance, the goal of Tesco is to achieve zero wasting, i.e. so that no waste from its stores would end up in disposal sites. The ideal situation, however, would be to work in a system of the so-called closed recycling loop. "The closed recycling loop is a management system, in which all materials are reused or returned, and subsequently recycled in a way that there is no waste produced. Creating a s closed-loop system requires the cooperation of the government, producers of packaging and products and retail. This approach to the use of packaging is based on the principles of a circular economy" [23].

If we included other international retail chains into our research, the issue of sustainability in the global dimension would be even broader, e.g. cooperation with suppliers from the third world countries that respect decent living and working conditions, non-inclusion of products from endangered species as well as products grown or reared in an undesired way for sale, energy intensity of production, etc.

Globalization brought to the Slovak market not only worldwide retail chains in various product categories [24,25], but also new elements of the retail store and its operation. Some of these components have started to be innovated by international marketers in Slovakia as a part of globalization processes on the basis of permanent sustainability around 2015 and this continues to our times. However, itis a question to discuss whether they do this because they want their responsible business to contribute to permanent sustainability and to the change of customer behaviour, or they carry it out in order to save costs, often in the amount of $30 \%$, which is a welcome side effect of these activities.

\section{References}

1. W. Sroka, R. Szanto, Corporate Social Responsibility and Business Ethics in Controversial Sectors: Analysis of Research Results. Journal of Entrepreneurship Management and Innovation 14, 3, 111-126 (2018)

2. J. Majerova, A. Krizanova, K. Zvarikova, Social media marketing and possibilities of quantifying its effectiveness in the process of brand value building and managing. In 9th International Scientific Conference on Financial Management of Firms and Financial Institutions (Ostrava, Czech Republic, 476-485, 2013)

3. V. Jurisova, Zero waste concept as a part of eco-innovations in global companies. Ibn Proceedings of the International Scientific Conference Globalization and Its SocioEconomic Consequences. Rajecke Teplice, Slovak Republic, 2107-2113 (2018)

4. D. Kollarova, D., M. Ungerova, Sensed atmosphere of the sacral structures, In Proceedings Book of the 11th European Symposium on Religious Art, Restoration \& Conservation. Valencia, Spain, 231 - 234 (2019)

5. V. Jurisova, CSR activities in environmental area - global trends and best practices. In Proceedings of the International Scientific Conference Globalization and Its SocioEconomic Consequences. Rajecke Teplice, Slovak Republic, 785-792 (2016)

6. Slovenská republika v čislach 2018. Bratislava: Štatistický úrad SR (2018)

7. Informácie a tipy pre obchodníkov. Availabale at: https://www.obchodnikroka.sk/files/OR\%202018_Informacie\%20a\%20tipy\%20pre\%20obchodnikov.pdf

8. Slováci sú lídrom v raste spotreby v Európe. In Stratégie, 24, 5, 28-29 (2018)

9. Martinus sa stal šiesty raz absolútnym vit’azom ocenenia Mastercard Obchodník roka. Available at : https://www.obchodnikroka.sk/tisk/Mastercard\%20Obchodnik\%20roka\%202018_vysledky_240419.pdf

10. TOP 30. Available at : https://www.tovarapredaj.sk/top30/ 
11. R. Miklencicova, Global Perception of Eco-Products and Ecological Marketing Acivities by Consumers. In Proceedings form International Scientific Conference Globalization and Its Socio-Economic Consequences. Rajecke Teplice, Slovak Republic, 1385-1393 (2016)

12. Vporadí 127. predajňu otvoril Lidl v Spišskej Novej Vsi. Available at: https://instoreslovakia.sk/2017/02/poradi-127-predajnu-otvoril-lidl-spisskej-novej-vsi/

13. Lidl vybudoval v Seredi najekologickejšie logistické centrum na Slovensku. Available at : https://www.spolocenskazodpovednost.sk/aktualita/zivotne-prostredie/lidlvybudoval-v-seredi-najekologickejsie-logisticke-centrum-na

14. Ide to aj bez emisií, Lidl sekologickou logistikou. Available at: https://www.spolocenskazodpovednost.sk/kamiony

15. Tesco otvorilo predajňu osvetlenú LED svietidlami. Available at: http://www.ekologika.sk/spravy/spravy/tesco-otvorilo-predajnu-osvetlenu-ledsvietidlami.html

16. Kaufland zavádza ekologické prepravky v predajniach po celej Európe. Available at: https://spolocnost.kaufland.sk/tlacove-spravy/aktualne-tlacovespravy/detail.y=2019.m=04.n=kaufland-prepravky.html

17. Kaufland prichádza s vlastnými ekosiet'kami na ovocie a zeleninu. Available at: https://spolocnost.kaufland.sk/tlacove-spravy/aktualne-tlacovespravy/detail.y=2019.m=06.n=ekosietky.html

18. Tesco dáva zbohom nerecyklovatelným plastovým obalom. Available at: https://tesco.sk/tesco-sr/pre-novinarov/tlacove-spravy/tlacova-sprava/tesco-davazbohom-nerecyklovatelnym-plastovym-obalom/\#report-734

19. Tesco na Slovensku už dosiahlo jeden z ciel’ov udržatel'ného rozvoja OSN. Available at : $\quad$ https://tesco.sk/tesco-sr/pre-novinarov/tlacove-spravy/tlacova-sprava/tesco-naslovensku-uz-dosiahlo-jeden-z-cielov-udrzatelneho-rozvoja-osn/\#report-773

20. A. Kusa, Z. Zazikova, Marketing strategies and communication problems of small and medium-sized e-shops in the Slovak market. In Proceedings from International Scientific Conference Marketing Identity, Smolenice, Slovak Republic, 339-346, (2017)

21. Lidl optimalizuje letáky, ročne ušetrí takmer 2400 ton papiera. Available at: https://www.spolocenskazodpovednost.sk/aktualita/zivotne-prostredie/lidloptimalizuje-letaky-rocne-usetri-takmer-2400-ton-papiera

22. Namiesto potravín prázdne regály. Bez opel’ovačov smutná realita. Available at: https://tesco.sk/tesco-sr/pre-novinarov/tlacove-spravy/tlacova-sprava/namiestopotravin-prazdne-regaly-bez-opelovacov-smutna-realita/\#report-763

23. Tesco dáva zbohom nerecyklovatelným plastovým obalom. Available at: https://tesco.sk/tesco-sr/pre-novinarov/tlacove-spravy/tlacova-sprava/tesco-davazbohom-nerecyklovatelnym-plastovym-obalom/\#report-734

24. J. Majerova, Analysis of Specifics in Buying Behavior of Slovak Customers in Internet Environment. In 2nd International Conference on Social Sciences Research (Hong Kong, China, 172-178, 2014)

25. E. Kicova, M. Nadanyiova, Brand as a tool of company's strategic marketing in practise. In Sports, health and management : 7th ESE international conference on sports, health and management. Madrid, Spain, 29-34 (2017) 